\title{
BAHAN AJAR MATA KULIAH BAHASA INGGRIS UNTUK MAHASISWA JURUSAN TEKNIK SIPIL POLITEKNIK NEGERI SEMARANG
}

\author{
Sriwahyuningsih Sulaiman ${ }^{\text {1) }}$, Suroso ${ }^{\text {1) }}$, Puji Wahyumi ${ }^{1)}$ ), Wildana Latif Mahmudi ${ }^{1)}$, \\ Yusetyowati $^{1)}$ \\ 1) Jurusan Teknik Sipil Politeknik Negeri Semarang \\ Jln. Prof. Soedarto, SH, Tembalang, Semarang, 50275 \\ Email: sriwahyuningsih.sulaiman@polines.ac.id, suroso@polines.ac.id
}

\begin{abstract}
ABSTRAK
Bahan ajar Bahasa Inggris adalah modul mata kuliah Bahasa Inggris yang berisi seperangkat materi yang disusun secara sistematis dengan menggunakan cara pandang bervisi SETS (Science, Environment, Technology, Society) dengan aplikasi berbagai materi pada mata kuliah lain sehingga memungkinkan tercipta lingkungan/suasana belajar yang dapat mempermudah mahasiswa untuk belajar lebih efektif dan efisien. Tujuan penelitian ini adalah menghasilkan bahan ajar mata kuliah Bahasa Inggris dengan model pembelajaran bervisi SETS yang sesuai untuk mahasiswa teknik, khususnya Teknik Sipil. Jenis penelitian yang digunakan adalah penelitian pengembangan $R \& D$ (Research and Development). Penelitian pengembangan digunakan untuk mendesain produk atau prosedur baru yang teruji secara sistematis di lapangan, dievaluasi, dikembangkan sedemikian rupa sehingga memenuhi kriteria efektivitas, kualitas atau kemiripan dengan suatu standar. Secara keseluruhan bahan ajar bahasa Inggris bervisi SETS yang disusun didalam penelitian ini mempunyai keterkaitan yang sangat baik yaitu tingkat keterkaitannya dengan mata kuliah lain yang ada di dalam kurikulum.
\end{abstract}

Kata kunci: SETS, bahan ajar, teknik sipil.

\section{PENDAHULUAN}

\section{Latar Belakang}

Bahasa Inggris sebagai bahasa kedua menekankan pengembangan kemampuan komunikatif, yaitu kemampuan untuk tidak saja menghasilkan kalimat-kalimat yang gramatikal, namun juga menggunakan kalimat-kalimat tersebut untuk berkomunikasi. Waluyo $d k k$ (2010) menyatakan bahwa apabila kemampuan berkomunikasi dianggap sebagai tujuan akhir pembelajaran, maka mestinya tidak hanya dipandang sebagai produk, tetapi juga sebagai proses. Implikasinya kemampuan berkomunikasi harus diajarkan, karena dengan diajarkannya komunikasi maka kemampuan linguistik juga akan diajarkan.

\begin{tabular}{llr}
\multicolumn{1}{c}{ Waluyo } & $d k k$ & $(2010)$ \\
mengemukakan & bahwa & model \\
pembelajaran yang & berorientasi pada \\
peningkatan & & kemampuan
\end{tabular}
berkomunikasi mahasiswa belum dapat berjalan secara efektif. Model pembelajaran dengan berpusat pada siswa (Student Centred Learning) dengan model silabus tematik menggunakan kegiatan belajar mengajar bahasa Inggris berbentuk penyelesaian tugas (Task Based Instruction) yang dikembangkan selama ini belum menunjukkan hasil yang memuaskan. Kurikulum yang sekarang digunakan identik dengan Theme Based Curricullum yang dikemukakan oleh Brown (1994). 
Materi pelajaran yang disusun berdasarkan tema atau topik seperti kesehatan masyarakat, kesadaran lingkungan, dan ekonomi global dengan kegiatan pembelajaran dengan membaca, menyaksikan video, mendiskusikan berbagai isu dan atau menuliskan artikel yang berkaitan dengan tema atau topik yang ditentukan. Richards (2001) mengatakan bahwa materi pelajaran yang digunakan dalam pengajaran yang komunikatif biasanya berbentuk teks, tugas,dan benda kongkret sebagai sarana mengembangkan penggunaan bahasa dalam kelas. Nunan (1990) mengemukkan bahwa kegiatan belajar mengajar yang efektif tergantung pada faktor-faktor seperti intensitas keterlibatan mahasiswa dalam pembelajaran (time on desk), pola penggunaan pertanyaan oleh dosen, pemberian balikan, keputusan pengelompokkan mahasiswa atas dasar jenis tugas yang diberikan, pengelolaan siswa, dan kejelasan tujuan dan arah pelajaran serta jenis dan lingkungan tugas yang harus diselesaikan.

Berdasarkan uraian di atas dapat dikemukakan bahwa peran bahasa Inggris sebagai bahasa kedua yang sangat penting karena menjadi sarana komunikasi yang menjadi salah satu dasar bagi mahasiswa untuk menyerap dan menguasai ilmu pengetahuan dan teknologi masih perlu terus diperbaiki kualitas pembelajarannya. Adapun langkah-langkah yang telah banyak dikembangkan adalah dengan mengembangkan model pembelajaran yang inovatif, pembuatan media pembelajaran maupun pengembangan bahan ajar yang diharapkan dapat membantu mahasiswa lebih mudah untuk memahami bahasa Inggris. Bahasa Inggris memiliki peran sangat penting terutama dalam membantu mahasiswa mengusai ilmu pengetahuan dan teknologi. Oleh karena itu kualitas pembelajaran bahasa Inggris perlu ditingkatkan dan peran bahasa Inggris dalam menunjang pelajaran lain perlu ditingkatkan. Binadja (1998) mengemukakan bahwa sains, ilmu pengetahuan sosial dan humaniora dapat dipadukan dalam suatu model pembelajaran yang akan saling mendukung sama lain yaitu model pembelajaran SETS (Science, Environment, Technology, dan Society). Dalam pembelajaran bervisi SETS, pada mata kuliah non sains seperti bahasa yang menjadi fokus perhatian adalah pada masalah-masalah kemasyarakatan atau produk kegiatan masyarakat. Perbedaan utama antara pembelajaran bervisi SETS pada bidang sains dan non sains adalah penekanan yang diberikan. Pada pembelajaran bidang sains, mahasiswa tidak hanya diharapkan memiliki kompetensi memahami konsep sains dan dapat menggunakannya tetapi juga memiliki minat yang dalam untuk menekuni bidang itu dalam kehidupannya di kemudian hari. Sementara itu, pada bidang sains, pengenalan pada sains dan teknologi akan dianggap mencukupi jika mahasiswa telah mengetahui peran dan keterkaitan sains dan teknologi tersebut pada bidang mereka sehingga mereka mampu memanfaatkan keberadaan keterkaitan tersebut.

Dari pemikiran di atas, dapat dikemukakan bahwa bahasa Inggris di jurusan teknik sipil dapat dipadukan dengan berbagai mata kuliah lain seperti Teknologi Bahan, mekanika rekayasa, dll baik mata kuliah yang diajarkan di klas teori maupun praktik di bengkel dan laboratorium sehingga dengan mempelajari bahasa Inggris selain kompetensi bahasa Inggris meningkat, mahasiswa dapat belajar pengetahuan lain misalkan topik pada mata kuliah mekanika rekayasa. Pemaduan bahasa Inggris dan mata kuliah lain tidak dilakukan 
berdasarkan topik kajian seperti halnya dengan model pembelajaran IPA terpadu, namun keterpaduan yang dimaksud dalam penelitian ini adalah bagaimana mengaitkan materi pelajaran bahasa Inggris dan materi pelajaran lain berdasarkan tema besar "Society" kemudian tema tersebut dikaji berdasarkan pendekatan SETS namun tetap menempatkan bahasa Inggris sebagai materi utama topik yang akan dikaji materi pelajaran lain ditujukan hanya untuk memperjelas materi bahasa Inggris yang akan disampaikan sedangkan materi pada materi pelajaran lain ditujukan untuk membuka cakrawala mahasiswa mengenai keterkaitan ilmu yang dipelajarinya dengan materi mata kuliah lain. Dengan demikian motivasi mahasiswa diharapkan akan semakin meningkat dan pemahaman mahasiswa terhadap materi pada mata kuliah lain semakin meningkat. Berdasarkan pemikiran tersebut, peneliti tertarik mengembangkan bahan ajar bahasa Inggris bervisi SETS yang diharapkan selain kompetensi bahasa Inggris meningkat, minat dan pemahaman terhadap materi mata kuliah lain juga akan semakin meningkatkan sehingga peran bahasa Inggris dalam mendukung perkembangan ilmu pengetahuan dan teknologi dapat terwujud.

Atas dasar uraian di atas maka permasalahan yang diajukan dalam penelitian ini adalah bagaimana bahan ajar mata kuliah bahasa Inggris bervisi SETS yang sesuai untuk mahasiswa jurusan Teknik Sipil.

Bahan ajar yang dimaksud dalam penelitian ini adalah modul mata kuliah Bahasa Inggris yang berisi seperangkat materi bahasa
Inggris yang disusun secara sistematis dengan menggunakan cara pandang bervisi SETS dengan aplikasi berbagai materi pada mata kuliah lain sehingga memungkinkan tercipta lingkungan/suasana belajar yang dapat mempermudah mahasiswa untuk belajar lebih efektif dan efisien.

\section{Tujuan Penelitian}

Adapun tujuan dari penelitian ini adalah menghasilkan bahan ajar mata kuliah bahasa Inggris dengan model pembelajaran bervisi SETS yang sesuai untuk mahasiswa teknik, khususnya jurusan Teknik Sipil Politeknik Negeri Semarang.

\section{TINJAUAN PUSTAKA}

\section{Pembelajaran Bahasa Inggris}

Bahasa Inggris sebagai bahasa kedua menekankan pengembangan kemampuan komunikatif, yaitu kemampuan untuk tidak saja menghasilkan kalimat-kalimat yang gramatikal, namun juga menggunakan kalimat-kalimat tersebut untuk berkomunikasi (Richards, 1991). Waluyo dkk (2010) menyatakan bahwa apabila kemampuan berkomunikasi dianggap sebagai tujuan akhir pembelajaran, maka hendaknya tidak hanya dipandang sebagai produk, tetapi juga sebagai proses, karena dengan diajarkannya komunikasi maka kemampuan linguistik juga akan diajarkan.

Waluyo dkk (2010) mengemukakan bahwa model pembelajaran yang berorientasi pada peningkatan kemampuan berkomunikasi mahasiswa sangat penting dilaksanakan. Model pembelajaran dengan berpusat pada mahasiswa (Student Centred Learning) dengan 
model silabus tematik menggunakan kegiatan belajar mengajar bahasa Inggris berbentuk penyelesaian tugas (Task Based Instruction) perlu dilakasankan dengan lebih sungguhsungguh lagi. dosen memberikan tugas kepada mahasiswa dan mahasiswa mengerjkan tugas tersebut, tugas di sini mengacu pada kegiatan kelas yang menghendaki mahasiswa menggunakan bahasa Inggris untuk memahami dan atau mengungkapkan makna. Dengan tugas itulah dosen membelajarkan siswa. Tugas - tugas tersebut diorganisasikan ke dalam tiga tahap kegiatan yaitu tahap kegiatan pra membaca, tahap kegiatan membaca, dan tahap kegiatan pasca membaca. Kurikulum yang sekarang digunakan identik dengan Theme Based Curricullum yang dikemukakan oleh Douglas Brown (2000). Materi pelajaran yang disusun berdasarkan tema atau topik seperti kesehatan masyarakat, kesadaran lingkungan, dan ekonomi global dengan kegiatan pembelajaran dengan membaca, menyaksikan video, mendiskusikan berbagai isu dan atau menuliskan artikel yang berkaitan dengan tema atau topik yang ditentukan. Richards (2001) mengatakan bahwa materi pelajaran yang digunakan dalam pengajaran yang komunikatif biasanya berbentuk teks, tugas,dan benda kongkret sebagai sarana mengembangkan penggunaan bahasa dalam kelas.

\section{Pembelajaran Bervisi SETS}

Mulai abad ke-19 banyak kalangan pendidik di Amerika Serikat menunjukkan ketidaksetujuannya terhadap anggapan bahwa semua mahasiswa lulusan sekolah menengah diarahkan dan dipaksa harus menjadi ilmuwan. Ketidaksetujuan ini akhirnya memunculkan gagasan lahirnya pendidikan bervisi sains, teknologi dan masyarakat STS (Science, Technology and Society). Dalam perkembangan kehidupan masyarakat, banyak permasalahan muncul yang sebelumnya tidak pernah ditemui. Masalah-masalahan tersebut diantaranya adalah perkembangan IPTEKS sangat berpengaruh terhadap kehidupan masyarakat dan lingkungan disekitarnya. Berdasarkan atas masalah-masalah yang timbul akibat perkembangan IPTEKS tersebut, mulai tahun 1996, Binadja mengembangkan suatu pendekatan pembelajaran yang bertujuan melatih kemampuan berfikir mahasiswa untuk mempelajari sains secara terpadu dengan teknologi, masyarakat, dan lingkungan SETS (Science, Environment, Technology and Society).

Dalam proses pembelajaran sehari-hari, kaitan antara pembelajaran bahasa Inggris dengan mata kuliah lain jarang sekali tersentuh. Sampai saat ini mulai banyak penelitian yang dilakukan dalam upaya mengkaitkan konsep bahasa Inggris sebagai sarana mengembangkan kemampuan berkomunikasi dengan materi dari mata kuliah lain. SETS (Science, Environment, Technology, dan Society) merupakan salah satu produk penelitian yang mengkaitkan konsep sains dan non sains dengan kehidupan sehari-hari (Puskur Balitbang Depdiknas, 2006:4).

Dalam pembelajaran, kondisi yang memungkinkan terjadinya proses belajar harus dirancang dan dipertimbangkan terlebih dahulu oleh 
perancang/guru. Visi SETS merupakan cara pandang sesuatu yang menyatakan segala yang diketahui di alam ini mengandung empat unsur yaitu sains, lingkungan, teknologi dan masyarakat. Pembelajaran bervisi SETS diartikan sebagai pendidikan yang akan menghasilkan lulusan yang dapat menerapkan pengetahuan yang diperolehnya guna meningkatkan kualitas hidup manusia tanpa harus membahayakan lingkungn fisik atau mental.

Berbeda dengan pendidikan SETS (Science, Technology and Society) SETS tidak hanya memperhatikan sains, teknologi dan masyarakat tetapi juga dampak positif dan negatif yang diakibatkan oleh sains dan teknologi yang dibutuhkan oleh masyarkat. Berbeda pula dengan pendidikan lingkungan EE (Environmental Education) SETS tidak hanya berfokus pada belajar di (in), untuk (for) dan tentang (about) lingkungan akan tetapi juga menemukan dan mengungkapkan penyebab utama permasalahan serta kemungkinan yang dapat menimbulkan dampak pada lingkungan di masa yang akan datang terutama dampak-dampak yang timbul akibat penggunaan sains dan teknologi untuk memenuhi kebutuhan masyarakat (Binadja, 1998).

Pada pembelajaran SETS, mahasiswa diajak untuk mengkaitkan unsur-unsur SETS yakni sains, lingkungan, teknologi dan masyarakat. Mahasiswa menghubungkan antara konsep sains yang dipelajari dengan teknologi penerapan konsep tersebut serta pengaruh teknologi tersebut terhadap masyarakat dan lingkungan baik kelebihan maupun kekurangannya.

\begin{tabular}{lcr}
\multicolumn{1}{c}{ Secara } & mendasar & dapat \\
dikatakan & bahwa & melalui \\
pembelajaran & bervisi & SETS
\end{tabular}
diharapkan peserta didik akan memiliki kemampuan memandang sesuatu secara terintegrasi dengan memperhatikan keempat unsur SETS sehingga dapat diperoleh pemahaman yang lebih mendalam tentang pengetahuan yang dimilikinya (Binadja,1998).

Binadja (1997) menyatakan bahwa pada pembelajaran fisika bervisi SETS dalam pelaksanaannya memiliki karakteristik: tetap memberi pengajaran mata kuliah yang bersangkutan, mahasiswa dibawa ke situasi untuk memanfaatkan konsep sains ke bentuk teknologi untuk kepentingan masyarakat, mahasiswa diajak berfikir tentang berbagai kemungkinan akibat yang terjadi dalam proses pentransferan sains tersebut ke bentuk teknologi, mahasiswa diminta untuk menjelaskan keterkaitan antara unsur sains yang dibahas dengan unsurunsur lain dalam SETS yang mempengaruhi keterkaitan antar unsur tersebut, mahasiswa dibawa untuk mempertimbangkan manfaat atau kerugian menggunakan konsep sains tersebut bila diubah dalam bentuk teknologi, dan dalam konteks konstruktivisme, mahasiswa dapat berbincang tentang SETS dari berbagai segi dan dari berbagai macam titik awal tergantung pada pengetahuan dasar yang dimiliki oleh siswa.

Binadja (1997) menyatakan bahwa buku-buku teks dari sekolah dasar sampai sekolah menengah atas selama ini cenderung hanya 
mempersiapkan mahasiswa menghadapi tes evaluasi hasil belajar saja. Buku-buku tersebut belum bisa membangun cara berfikir mahasiswa secara terintegrasi apabila mereka telah menyelesaikan pendidikannya. Akibatnya ketika mahasiswa menamatkan pendidikannya tidak tahu harus kemana untuk menolong dirinya sendiri ingin melanjutkan pendidikan atau bekerja.

\section{METODE PENELITIAN}

\section{Desain Penelitian}

Jenis penelitian yang digunakan adalah penelitian pengembangan (Research and Development). Penelitian pengembangan digunakan untuk mendesain produk atau prosedur baru yang teruji secara sistematis di lapangan, dievaluasi, dikembangkan sedemikian sehingga memenuhi kriteria efektivitas, kualitas atau kemiripan dengan suatu standar (Borg dan Gall, 1983). Model pengembangan yang digunakan dalam penelitian ini adalah model yang dikembangkan oleh Sukmadinata (Syaodih 2007:182). Model ini meliputi 2 tahap pengembangan yaitu studi pendahuluan dan pengembangan bahan ajar.

\section{Teknik Pengumpulan Data}

Dalam penelitian ini digunakan teknik sebagai berikut: a) Wawancara dilakukan dua kali. Wawancara pertama yang dilakukan sebelum penelitian dimulai bertujuan untuk mengungkap faktor-faktor pendukung pembelajaran dan wawancara kedua dilakukan terhadap seorang subyek dalam penelitian uji coba terbatas untuk mengungkap tanggapan mahasiswa terhadap bahan ajar yang dikembangkan. b) Angket: diberikan kepada subyek uji coba dengan kelompok yang lebih luas yang meliputi semua subyek penelitian. Angket ini berisi serangkaian pertanyaan/pernyataan untuk mengungkap tanggapan subyek terhadap bahan ajar yang dikembangkan serta kritik dan saransaran responden.

\section{Analisis Data}

Analisis data dilakukan melalui Analisis Hasil Wawancara dan Analisis Tanggapan mahasiswa Terhadap Bahan Ajar yang dapat dijelaskan sebagai berikut: a) Analisis Hasil Wawancara. Data hasil wawancara dianalisis secara deskriptif kualitatif untuk memberikan penjelasan secara rinci tentang kendala yang dialami mahasiswa dalam mempelajari bahan ajar serta pendapat mahasiswa tentang bahan ajar yang sedang dikembangkan. b) Analisis Tanggapan mahasiswa Terhadap Bahan Ajar. Pada analisis tahap ini, data diperoleh dari skor angket tanggapan mahasiswa terhadap bahan ajar yang diberikan. Analisis dilakukan dengan analisis deskriptif. Tanggapan mahasiswa terhadap bahan ajar diperoleh dengan menentukan prosentase sub variabel menurut persamaan berikut:

$$
\mathrm{Ps}=\frac{\mathrm{S}}{\mathrm{N}} .100 \%
$$

Ps $=$ prosentase sub variabel

$\mathrm{S}=$ jumlah nilai tiap sub variabel

$\mathrm{N}=$ jumlah skor maksimum

Kategori tanggapan mahasiswa tiap sub variabel adalah sebagai berikut:

Jika $0 \%<$ skor $\leq 20 \%$ tidak baik Jika $21 \%<$ skor $\leq 40 \%$ kurang baik 
Jika $41 \%<$ skor $\leq 60 \%$ cukup baik

Jika $61 \%<$ skor $\leq 80 \%$ baik

Jika $81 \%<$ skor $\leq 100 \%$ baik sekali

\section{HASIL DAN PEMBAHASAN}

Secara keseluruhan hasil kuisioner menunjukan bahwa materi bahan ajar bahasa Inggris bervisi SETS dengan tingkat keterkaitan yang sangat tinggi yaitu lebih dari lima mata kuliah. Berdasarkan hasil kuisioner diperoleh data sebagai berikut:

\section{Topik Safety Rules}

a. Topik Safety Rules terkait dengan sangat baik dengan science, topik ini dikaitkan dengan konst. Baja, Pengukuran dan pemetaan, Bahan Bangunan, dan Mekanika Tanah (teori) dan tujuh (7) mata kuliah praktik yaitu: Bengkel Batu (masonry), Form Work (perancah), Praktik Kayu, Praktik Baja, Pengukuran dan Pemetaan, Bahan Bangunan, Mekanika Tanah (Hidrolika) dan empat (4) materi teori yaitu konstruksi baja, pengukuran dan pemetaan, bahan bangunan dan mekanikia rekayasa.

b. Topik Safety Rules terkait dengan baik dengan aspek environment. Topik ini dikaitkan dengan tiga (3) mata kuliah teori yaitu: Pengukuran dan Pemetaan, Bahan Bangunan dan Mekanika Tanah (Hidrolika) dan empat (4) mata kuliah praktik yaitu Form Work, Praktik Kayu, Praktik Baja, dan Masonry.

c. Safety Rules terkait dengan baik dengan aspek technology. Topik ini dikaitkan dengan tiga (3) mata kuliah teori yaitu: Pengukuran dan
Pemetaan, Bahan Bangunan dan Mekanika Tanah (Hidrolika) dan empat ( 4) mata kuliah praktik yaitu Form Work, Praktik Kayu, Praktik Baja.

d. Safety Rules terkait dengan baik dengan aspek technology. Topik ini dikaitkan dengan enam (6) lingkungan kerja terkait dengan profesi yaitu: teknisi, kontraktor, surveyor, pelaksana K3 dan foremen.

Topik Tools, Materials, Containers, Instruments and Numbers

a. Topik Tools, Materials, Containers, Instruments and Numbers diperoleh data bahwa: Topik Tools, Materials, Containers, Instruments and Numbers berhubungan sangat baik dengan Sembilan (9) mata kuliah teori yaitu: Bahan Bangunan, Pengukuran \& Pemetaan, Mekanika Tanah (Soil Mecanics), Gambar Teknik, Mekanika Rekayasa, Konstruksi Baja, Matematika, Ekonomi, Fisika.

b. Topik Tools, Materials, Containers, Instruments and Numbers terkait sangat baik dengan science yaitu lima (5) mata kuliah praktik yaitu: Bahan Bangunan, Pengukuran \& Pemetaan, Gambar Teknik, Mekanika Tanah, Praktik Baja. Dan berhubungan dengan mata kuliah praktik yaitu: Form Work, Praktik Kayu, Praktik Baja, Lab mekanika Tanah.

c. Topik Tools, Materials, Containers, Instruments and Numbers terkait sangat baik dengan environment yaitu enam 
(6) mata kuliah praktik yaitu: Praktik kayu, Batu, Baja, Lab. Pengukuran \& Pemetaan, Mekanika Tanah, dan Form Work

d. Topik Tools, Materials, Containers, Instruments and Numbers terkait sangat baik dengan technology di lingkungan kerja terkait dengan tujuh profesi yaitu: logistic, perencana, drafter, penguji lab, teknisi, dan foremen, surveyor.

\section{Modular System}

a. Topik Modular System terkait sangat baik dengan science terlihat dari data bahasan berhubungan dengan lima (5) mata kuliah praktik yaitu: gambar teknik, konstruksi baja, beton, mekanika rekayasa, manajemen konstruksi. Dan berhungan dengan mata kuliah praktik empat (4) antara lain kayu, formwork, baja, dan bahan bangunan.

b. Topik Modular System terkait sangat baik dengan technology terlihat dari data bahasan berhubungan dengan tiga (3) mata kuliah teori yaitu: gambar teknik, beton, baja. Dan berhubungan dengan mata kuliah praktik empat (4) antara lain kayu, formwork, baja, dan batu

c. Topik Modular System terkait baik dengan environment yaitu enam (6) yaitu berapa profesi yaitu drafter, pelaksana, konsultan, surveyor, perencana dan Kontraktor.

Secara keseluruhan bahan ajar bahasa Inggris bervisi SETS yang disusun didalam penelitian ini mempunyai skor keterkaitan 4,2 ini artinya tingkat keterkaitannya dengan mata kuliah lain yang ada didalam kurikulum sebesar $84 \%$ dengan predikat sanga baik.

\section{SIMPULAN}

Berdasarkan analisis penelitian dapat disimpulkan bahwa:

1. topik Safety Rules berkaitan dengan tujuh (7) mata kuliah praktik dan empat mata kuliah teori.

2. Topik Tools, Materials, Containers, Instruments and Numbers sangat erat terkait dengan sembilan (9) mata kuliah praktik dan lima mata kuliah teori.

3. Topik Modular system terkait cukup baik dengan tiga (3) mata kuliah teori yang diberikan di studi program teknik sipil dan empat (4) mata kuliah praktik.

4. Secara keseluruhan dapat disimpulkan bahwa materi ajar bahasa Inggris yang disusun terpadu dengan visi SET (Science, Environment, Technology).

5. Dengan materi ajar bahasa Inggris yang terpadu diharapkan mahasiswa lebih mudah dalam mempelajari bahasa Inggris karena sudah mempunyai basic knowledge keteknikan dan dapat memotivasi mahasiswa dalam mempelajari belajar bahasa Inggris.

\section{SARAN}

Penelitian ini perlu dilanjutkan untuk membuat model seluruh topik materi ajar yang dilengkapi dengan latihan-latihan yang sesuai topik materi ajar selama satu semester yang terpadu dengan mata kuliah lain yang sesuai dengan kurikulum dan dibuat 
hand out untuk memudahkan mahasiswa dalam belajar.

\section{DAFTAR PUSTAKA}

Binadja, Ahmad, 1997. The Nature of SETS Education. Makalah Disajikan dalam Seminar Language in the Context of Science and Mathematic di Semarang 4-6 Mei 1998.

Binadja, Ahmad, 1998. SETS a Popular way to Communicate Science. Makalah Disajikan dalam Pelatihan An Early Start to SETS Education, di Penang Malaysia.

Borg, W.R.\& Gall, M.D. 1983. Educational Research: An introduction. New York \& London: Longman.

Brown, H. D. 1994. Teaching by Principles an Interactive Approach to Language Pedagogy. Englewood Cliffc, New Jersey: Prentice Hall Regents.

Brown, H. Douglas. 2000. Principles of Language Learning and Teaching. New York: Longman.

Depdiknas. 2006. Model Pengembangan Silabus Mata Pelajaran dan Rencana Pelaksanaan Pembelajaran IPA Terpadu. Jakarta: Puskur Balitbang Depdiknas.

Richard, Jack C. 2001. Curriculum Development in Language Teaching. Cambridge University Press. Cambridge.
Richard, Jack C. 1991. The Dilema of Teacher Education in Second Language Teaching. dalam Richard, Jack $\mathrm{C}$ and Nunan, David (eds). Second Language Education.Cambridge:

Cambridge University Press.

Richard, Jack and Nunan, David (eds) 1990. Second Language Teacher Education. Cambridge: Cambridge University Press.

Syaodih, N. 2007. Metode Penelitian Pendidikan. Bandung: PT.Remaja Rosdakarya.

Waluyo, Kunardi, Joko, N. 2010. Kemampuan Guru Mengimplementasikan Pendekatan Komunikatif dalam Pengejaran Bahasa Inggris di SMA dan SMK Kota Surakarta. Jurnal Penelitian Paedagogia Hal: 87-97. 
